\title{
Dengue Virus: Clinical Manifestations and Advances in Diagnosis, Treatment with a Special Focus on Strategies to Limit Mosquito Spread
}

\author{
Jissin Mathew $(\mathbb{D})$, Vani C.* ${ }^{(D)}$, Pinaki Dey $\mathbb{D}^{\mathbb{D}}$, Francis Paul $(\mathbb{D}$ and Merlin Joice Mary \\ Department of Biotechnology, School of Agriculture and Bio Sciences, Karunya Institute of Technology and Sciences, \\ Coimbatore - 641 114, Tamil Nadu, India.
}

\begin{abstract}
Dengue is a viral disease that is transmitted by Aedes aegypti mosquito worldwide. It is globally prevalent and has no effective treatment till date. Approximately $\mathbf{5 0 , 0 0 0}$ people suffer from dengue annually, of which $10 \%$ of the total cases involved are due to dengue hemorrhagic fever. This creates a very distressing situation which puts forth a need for development of an effective anti-dengue agent to combat this epidemic infection. The use of bioinformatics tools, high performance computing and molecular modeling programs has been leading the advancements in designing and in silico searching of therapeutically active molecules that can be used against Dengue. For drug designing the bioinformatics is evolving the docking studies of NS3 pro and Envelope protein of DENV 2 and DENV 3 with new drug design tools that are available in public using Artificial Neutral Network (ANN) and Hidden Markov Model (HMM). Most chemical insecticides that are used for the eradication of mosquito vectors are not safe because of their harmful side effects to living organisms. This review focus about the various immunological manifestations of Dengue viral infection. There is a need of using biocontrol agents that includes the use of microorganisms, fishes and its metabolites for the elimination of vectors and dengue outbreaks.
\end{abstract}

Keywords: Dengue fever, Immunology, Transmission, Biocontrol agents.

*Correspondence: vani@karunya.edu; +91-9842215562

(Received: 10 April 2019; accepted: 08 August 2019)

Citation: Jissin Mathew, Vani C., Pinaki Dey, Francis Paul and Merlin Joice Mary, Dengue Virus: Clinical Manifestations and Advances in Diagnosis, Treatment with a Special Focus on Strategies to Limit Mosquito Spread, J Pure Appl Microbiol., 2019; 13(3): 13971405. https://doi.org/10.22207/JPAM.13.3.10

C The Author(s) 2019. Open Access. This article is distributed under the terms of the Creative Commons Attribution 4.0 International License which permits unrestricted use, sharing, distribution, and reproduction in any medium, provided you give appropriate credit to the original author(s) and the source, provide a link to the Creative Commons license, and indicate if changes were made. 


\section{INTRODUCTION}

Dengue fever is a rapidly spreading diseases which threatens inhabitants of tropic and subtopic regions of the world. According to the National Vector Borne Disease Control 2016, it is estimated to cause upto 390 million infections and approximately 500,000 hospitalizations annually. Dengue fever is an acute viral disease transmitted through mosquitoes of Aedes species. There are 5 known dengue serotypes (DENV-1, DENV-2, DENV-3, DENV-4 and DENV-5), all of which can lead to inapparent infection syndrome to classic dengue fever (DF), Dengue hemorrhagic fever (DHF) and Dengue shock syndrome (DSS) with vascular leakage and shock (Mustafa et al., 2015). The dengue viral infections are asymptomatic but secondary infections with different serotypes increase the risk of severity. The massive entry of dengue virus involves recognizing one or more cell receptors. During the endocytosis pathway; the cellular vacuolar ATP leads acidification on the cell surface thereby causes structural manipulation in the envelope protein; enabling viral genome release into the cytoplasm (Niyati and Ira, 2016). In primary DENV infection, the immune response will protect any future secondary infections and may also defends or provocate high disease severity with different DENV serotype infection subsequently. This severity may be due to the effect of serotype cross reactive T-cells or antibody-dependent enhancement (ADE) as like observed with other viruses such as Zika virus (Khandia et al., 2018). This will in turn cause cross reactive antibodies to intend viral structural proteins in order to accelerate virus pestilence of Fcg receptor - gait cells. The antibodies related to Flavivirus has a challenge for serological diagnostic tests because of its binding not only to that exact virus but also with other Flaviviruses. The presence of disease enhancing effect of cross reactive antibodies is the principle of antibodydependent enhancement (ADE). The hypothesis of $A D E$ states that antibodies resulting from the infection of DENV serotype enhance disease with subsequent infection of different serotype. The non-neutralized cross reactive antibodies ease the antibody non-neutalised virus complexes into mononuclear phagocytic cells (Niyati and Ira, 2016 and Khandia et al., 2018). Dengue virus has a $10.7 \mathrm{kbp}$ of positive strand RNA genome which is computed with polyproteins that are post translationally severed into envelope structures, membranes, capsids and 7 other proteins which are non-structural. Previous research findings have reported about a nonstructural $48-\mathrm{kD}$ glycosylated protein NS1, which plays an effectual role in viral replication and immune vagueness (Nivedita et al., 2013).

Initially translation of NS1 forms monomer and are glycosylated in the Endoplasmic Reticulum, rapidly incarnated into dimer that involves amalgamation of infected cells with the viral replication complex on the surface of the ER membrane, plasma membrane association by glycophosphatidyl inositol linkage, semblance of soluble lipophilic hexamer which are secreted by infected cells or by the binding of hexameric NS1 back to the surface of uninfected cells through glycosaminoglycan interactions (Gutsche et al., 2011). According to WHO, the epidemiological analysis of dengue has kept India under category $\mathrm{A}$; due to is consistent communal health problems, paramount cause of hospitalization and death rates among children and also due to hyperendemicity with all five dengue virus serotypes. At present, the increased risk of dengue is due to factors such as changes in lifestyle, rapid urbanization and improper water storage practices which leads to rapid escalation in the breeding of mosquitoes (Natasha et al., 2013). The review presents the details about how far dengue virus and its manifestation are involved in regarding public health concern, prevention and treatments by understanding the mechanism of serious forms of Dengue Hemorrhagic Fever and Dengue Shock Syndrome.

\section{Mode of Transmission}

The life cycle of Aedes aegypti is explained in two phases: Aquatic phase involves Larvae and Pupae form; and Terrestrial Phase includes eggs and Adult stages. Because of its fastest adaptations to the new environment there is a high chance of occurrence of dengue outbreak and it should be considered as an important infection affecting public health (Helenice et al., 2018). The transmission of dengue virus is aided by mosquitoes by feeding on blood of infected persons. The viral replication smoothly starts by infecting and replicating in the midgut epithelium of the vector and continuous its replication in 
the insect hemolymph and are transmitted to other organs finally reaching salivary glands after 10-14 days of exposure thereby aiding vector to bite another person for blood meal (Nedjadi et al., 2015). The entry of DENV is facilitated by the viral envelope glycoprotein receptor - mediated endocytosis to its targets such as dendritic cells, macrophages and monocytes. The glycoprotein $\mathrm{E}$ is the major component which aids the viral entry. It is also reported as the viral entry is mediated via clathrin-mediated endocytosis pathway (RigauPerez 2006). The DENV pathway is mainly based on the viral strains and the cell type.

In classical Endocytic Pathway, the clathrin - coated vesicles will uptake the receptor - bound virus and undergo fusion with endosomes to deliver into the cytoplasm. The glycoprotein $E$ undergoes conformational rearrangement due to $\mathrm{pH}$ reduction of the endosomes (Van Dam and Walton, 2008). As it is discussed the viral Envelope protein (E) plays a major role in its replication process. The ectodomain of the Envelope protein are made of three functional domains: a) ED I contributes central region; 8 stranded $\lambda$ barrel involved in the organization of structure. $b$ ) ED II- Dimerization domain has $12 \beta$ strands and $2 \alpha$ helices involved in the process of highly conserved fusion loop. c) ED III are immunoglobulin like domain of $10 \beta$ strands involved in receptor binding process. According to the different serotypes the structure of the three domains also differs (Niyati and Ira, 2016).

\section{Clinical Manifestations}

In dengue fever, the infection starts suddenly and undergoes 3 phases. They are, initial febrile phase, critical phase and the spontaneous recovery phase.

\section{Febrile phase}

The main characteristics of the Febrile phase are headaches, vomiting, myalgia, high temperature, joint pain and macular rashes. Mild hemorrhagic manifestations like palpable liver, petechiae and bruising at the venepencture site are seen. The febrile phase may last for 3-7 days after the onset but after which the patients will recover normally without any further complications.

\section{Critical phase}

The critical phase is manifested by the begining of systemic vascular leak syndrome followed by an increase in hemoconcentration, pleural effusions, ascites and hypoproteinemia. During the transfugration from febrile from 4-7 days the critical phase with clinical complications occurs. The dengue shock syndrome is diagnosed when the pulse pressure is narrowed to $20 \mathrm{~mm} \mathrm{Hg}$ or less and peripheral vascular collapse observed. Once hypotension develops, systolic pressure abruptly lowers, irreversible shock and finally death may follow despite rigorus attempts of resuscitation. These continual deterioration of condition includes nausea, progressive severe abdominal pain, and tender enlarged liver, fluctuating hematocrit level that corresponds to thrombocytopenia, serosal effusions, bleeding of mucosa and lethargy or restlessness (Cameron et al., 2012). Other appalling manifestations, such as, myocarditis, encephalopathy, liver failure occur, and minimal associated plasma leakage are also frequently detected.

\section{Recovery Phase}

The change in permeability nature of vascular tissues is only temporary, after 48 to 72 hours the patient quickly recovers to a normal state with onset improvement in the patient's symptoms. A second rash may arise, which ranges from a mild maculopapular rash to a severe, itchy lesion suggesting leukocytoclastic vasculitis and it resolves with desquamation over a period of 1 to 2 weeks. However, adults may have severe fatigue that lasts for several weeks after convalescence (Cameron et al., 2012).

Clinical manifestation of the serious illness includes cold limb extremities, low pulse, low urine output, signs of mucosal bleeding and abdominal pain. One such report expanded the clinical illness involving gastrointestinal and hepatic syndrome with illness of asymptomatic increase of liver enzymes, fulminant hepatc failure, acute pancreatitis, peritonitis, spleen rupture, acalculous cholecysitis, subacute intestinal obstruction and kidney failure (Bijaya et al., 2019).

\section{Diagnosis and Treatment}

The IgM immunoassay (MAC-ELISA) procedure is widely used for the rapid confirmation of viral illness (Rigau-Perez 2006). False negative result may be obtained by this assay if the samples were obtained from the patients within the six days of dengue incidence. The confirmation of IgM assay as positive occurs when both the 
acute and convalescent specimens are analysed by hemagglutination inhibition (HI) or enzyme immunoassays. These assays provide definitive serologic testing for acute dengue virus infection. The serum sample in acute phase can be tested for the patient with negative result in IgM assay which indicates the existence of the dengue viral NS1 antigen (Blacksell et al., 2007).

IgM antibodies specific to dengue virus are detected during sixth day of illness in blood specimen by using MAC-ELISA persist for 30 to 90 days. On comparing with $\mathrm{HI}$ assay the sensitivity and specificity of MAC-ELISA is much lower. Reduction in the sensitivity and specificity of MACELISA assay is due to blunting of IgM antibody response in secondary dengue virus infections and potential for positive results to reflect acute dengue virus infection. (Vaddadi and Vaddadi, 2015). Confirmation of concurrent infection is mainly by virus isolation and detection of viral RNA or protein in acute phase serum. RT-PCR technique ia widely performed for epidemiologic purposes as a part of clinical research. The most preferred specimens for virus isolation is serum and plasma. The virus can be isolated from liver tissues once it is cleared from the serum. RT-PCR is the only effective method for virus detection in a very short period (one to two days) and it has sensitivity towards viral isolation (Chien et al., 2006).

Dengue viral proteins in tissue samples can be detected using immunohistochemical staining. In tissue samples, the high yields of viral proteins are detected in liver tissues. During the first five to six days of illness the nonstructural protein 1 (NS1) of dengue virus can be seen in plasma (Moi et al., 2013). Plasma leakage in DHF can be detected by Ultrasound technique (Srikiatkhachorn et al., 2007). No specific treatments vaccines are available for pestilence diseases.

Currently new approaches for rapid diagnosis of dengue is in process as it includes micro/paper fluidics, in vivo micropatches, Isothermal PCR, Peizoelectric and Electrochemical detection (David et al., 2017). Experiments in Vietnam, Australia and other countries suggest successful invasion of Wolbachia-infected mosquitoes into natural openings of female mosquito leads genetic changes by developing to new strains (Anum et al., 2016).

\section{Biological Control of Mosquito Vectors}

The chemical insecticides that are used for the eradication of mosquito vectors are not safe because if its harmful side effects to living beings. There is a need of using biocontrol agents that includes the use of microorganisms, insects, fishes and its compounds, as have been applied for other emerging viruses like Zika virus (Singh et al., 2018). Essential arthropod predators dragonflies or mosquito hawks and the aquatic stage of damselflies prey on mosquitoes which are not as effective mosquito control as dragonflies. Two beetles such as predaceous diving beetle and water scavenging beetle they readily eat the aquatic stages of mosquitoes. Spiders become mosquito predator by encasing and eating the mosquito that inadvertently flies into a spider's web.

Carassius auratus, Poecilia reticulate, Lepomis macrochirus and Siluriformes $s p$. are effective in reducing the number of mosquitoes under field conditions. Among these, the most important fish predator is the Gambusia affinis, commonly known as the mosquito fish (Mario et al., 2012).

One such experimental procedure reported that most of the birds, tadpoles infrequently feed on mosquito larvae. A. aegypti mosquito usually lay eggs in discarded plastic containers, tires, etc. which are filled with water. The removal of these water filled containers from the environment with many anti-dengue campaigns as a part of vector control (Muhammad 2015). The red-eared slider turtle is the most turtle that feeds on mosquito larvae.

One such scientific study reported instead of eradicating the vector Wolbachia pipientis infected mosquitoes can shift the age and thereby it shortens the lives of dengue-infected mosquitoes. When a mosquito is infected with dengue virus, it takes about eight to twelve days for the transmission of infection to another healthy person. The mosquito then continue to infect people throughout its lifetime, generally around three to four weeks. An infected mosquito with short lifetime only have a short term opportunity for the transmission of dengue (McMeniman et al., 2009).

Synthetic pyrethroids is the most harmful chemical to the users, while Bacillus thuringiensis 


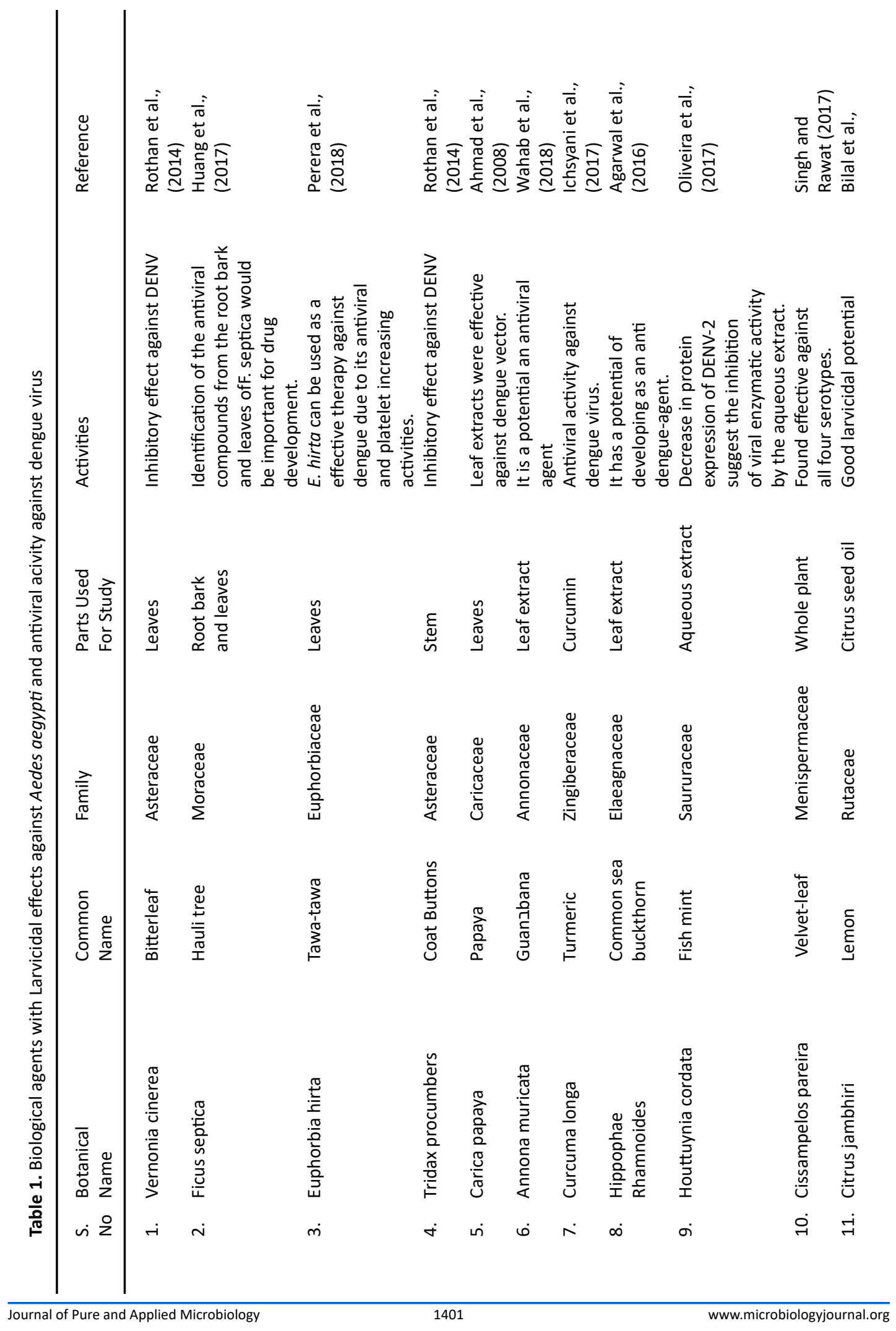




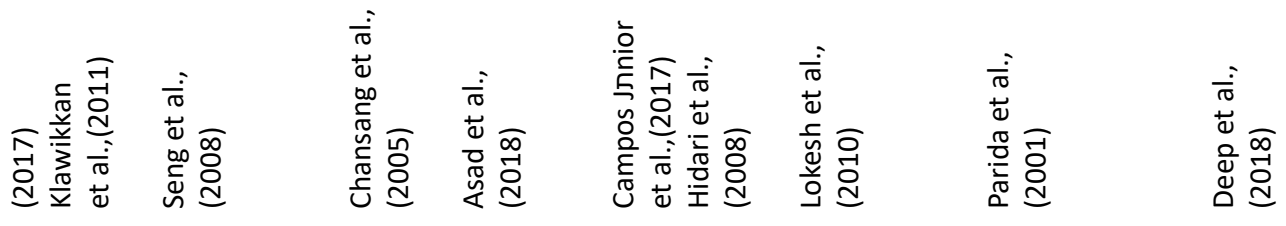

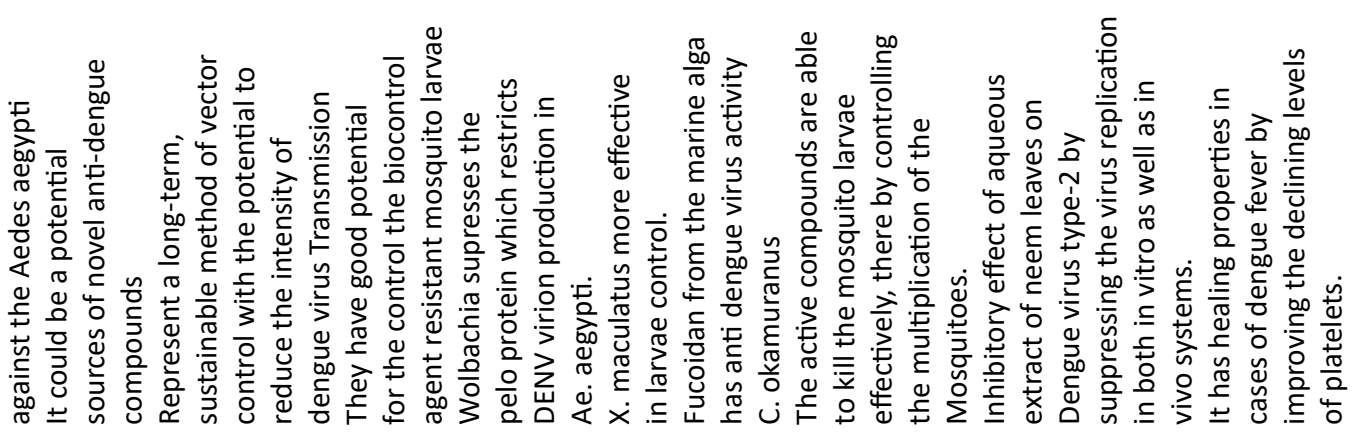

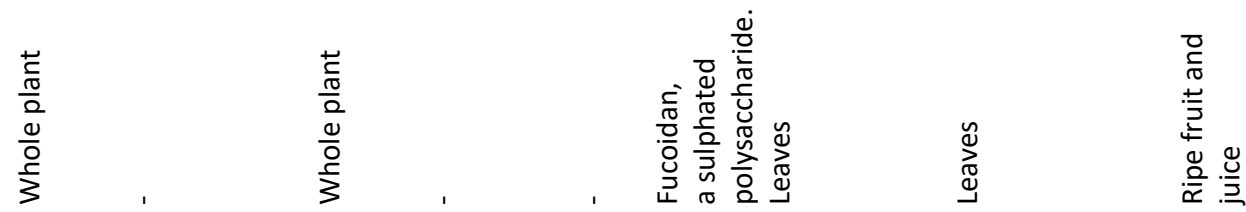

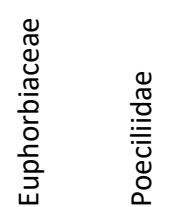<smiles>CC(C)CC(=O)O</smiles><smiles>CC(C)C</smiles><smiles>CC(C)C</smiles>

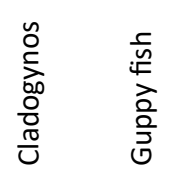

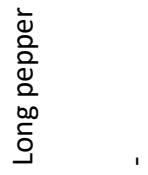

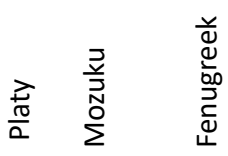<smiles>[CH]=C</smiles>

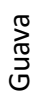

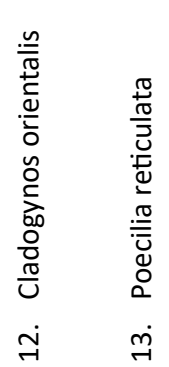

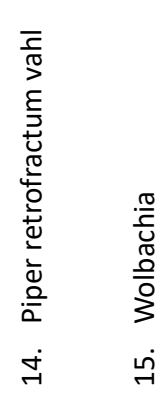

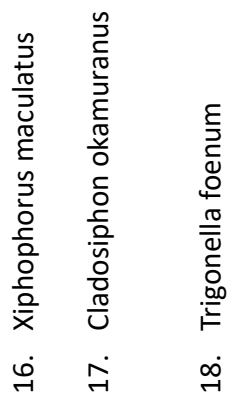

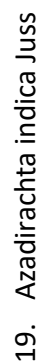

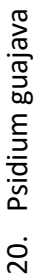


and insect growth regulators are among the least toxic. Bioformulation based on the bacteria like Bacillus sphaericus and Bacillus thuringiensis are the well-known examples of a bio insecticide, which is effective against larval population in terms of its cost of production and has less harm to the people and environment.. A Bacillus $s p$. spray performs its activity by insect gut pralyzation (depending on the strain used or mosquito). The bacterial protein is the active ingredient which paralyzes the gut. It is used in formulations instead of viable bacterial spores. Thus, the spread of disease does not continue among the insect population. The potential virus production at low are used against $A$. aegypti has not yet developed in developing countries; neither the production of protozoans and microsporidians through artificial cultures were evaluated as parasites of the dengue vector (Mario et al., 2012). Beneficial nematodes are the example of live natural enemies that are inundatively released. These nematodes travel through the soil or its surface, and actively attack their insect hosts. Inside the body, these release the symbiotic bacteria, which rapidly multiply and kill the host. The nematodes feed on the bacteria and insect tissue which then mate and reproduce. After one to two weeks, new young nematodes then emerge from the insect dead body and they seek new hosts. One such recent study reported that the toxic compound of Pseudomonas fluorescens KUN2 strain in petroleum ether successfully showed its larvicidal activity against dengue vector Aedes aegypti (Lalithambika and Vani, 2016). Studies about this cytotoxin and development of this anti-larvicidal drug will be effective for the treatment of Dengue fever in a cost effective manner.

\section{CONCLUSION}

Prevalence of Mosquito borne diseases are the most prevalent world's most health hazardous problems. Several species belonging to the genera Anopheles, Culex and Aedes are vectors for pathogens of various diseases like malaria, filariasis, Japanese encephalitis, dengue and dengue hemorrhagic fever, yellow fever and chikungunya. Number of approaches has been developed to control mosquito spread. Mosquito borne disease is aimed at killing mosquito at larval stage with integrated pest management and effective biological agents. Concluding this review by encouraging the need for more extensive research with valid scientific discoveries by taking into the account of controlling the spread of infection and reducing mortality incidence associating public health. Development of antiviral drugs is the key route for the future insight in dengue pathogenesis thereby we can tackle underlying mechanism involved in Dengue Hemorrhagic Fever and Dengue Shock Syndrome.

\section{ACKNOWLEDGEMENTS}

We would like to thank Department of Biotechnology, Karunya Institute of Technology and Sciences and also would like to thank Mathew C Abraham, Susan Mathew, Blesson Mathew for all their support.

\section{CONFLICT OF INTEREST}

The authors declares that there is no conflict of interest.

\section{AUTHORS' CONTRIBUTION}

All authors have made substantial, direct and intellectual contribution to the work and approved it for publication.

\section{FUNDING}

This study was supported and funded by University Grant Commission - Maulana Azad National Fellowship (Grant Number - F117.1/2016-17/MANF-2015-17-KER-69816).

\section{DATA AVAILABILITY}

All datasets generated or analyzed during this study are included in the manuscript.

\section{ETHICS STATEMENT}

This article does not contain any studies with human participants or animals performed by any of the authors.

\section{REFERENCES}

1. Mustafa M.S., Rasotgi V., Jain S., Gupta V. Discovery of fifth serotype of dengue virus (DENV-5): a new public health dilemma in dengue control. Medical journal armed forces India, 2015; 71(1): 67-70. https://doi.org/10.1016/j.mjafi.2014.09.011.

2. Niyati K., Ira K. Dengue Fever: Causes, Complications, and Vaccine Strategies. Journal of Immunology Research, 2016; 14: 27-31. https://doi. 
org/10.1155/2016/6803098.

3. Khandia R., Munjal A., Dhama K., Karthik K. Tiwari R., Malik Y.S., Singh R.K., Chaicumpa W. Modulation of Dengue/Zika Virus Pathogenicity by Antibody-Dependent Enhancement and Strategies to Protect Against Enhancement in Zika Virus Infection. Frontiers in Immunology, 2018; 23(9): 597-617. https://doi.org/10.3389/fimmu.2018.00597.

4. Nivedita G., Sakshi S., Amita J., Umesh C.C. Dengue in India. Indian Journal of Medical Research, 2012; 136(1): 373-390.

5. Gutsche I., Fasseli C., James E.V., Jerome S., Jacues D., Myriam E., Eric L., Pierre C., Thomas K., Francoise M., Eric G., Felix A.R. Secreted dengue virus nonstructural protein NS1 is an atypical barrel-shaped high density lipoprotein. Proceedings of the National Academy of Sciences USA. 2011; 108(19): 8003-8008. https://doi.org/10.1073/pnas.1017338108.

6. Helenice O.F., Daniela R.C., Fernando L.P.S., C'elia A.R., Margarida V.P., Dylan J., Marianna C., Rog'erio A.O., Luiz G.L. Genetic Algorithm For Optimization Of The Aedes Aegypti Control Strategies. Pesquisa Operacional, 2018; 38(3): 389-411. https://doi. org/10.1590/0101-7438.2018.038.03.0389.

7. Nedjadi T., Sherif E.K., Sayed S.S., Philippe D., Ghazi D., Esam A. Tackling dengue fever: Current status and Challenges. Virology Journal, 2015; 12(2): 212-229. https://doi.org/10.1186/s12985-015-0444-8.

8. Natasha E.A.M., Mikkel B.Q., Annelies W. Epidemiology of dengue past, present and future prospects. Clinical Epidemiology, 2013; 5(1): 299-309. https://doi.org/10.2147/CLEP.S34440.

9. Michela B., Karin A., Rene A., Cecile B., Bruno C., Shelley C., Bruno C., Etienne D., Xavier D.L., Ernest A.G., Gilda G., Jonathan M.G., Rolf H., Anna M.J., Helene M., Erika J.M., Eloise M., Andrea M., Maro M., Gregory M., Johan N., Raymond J.O., Jingshan R., Barbara S., Silvia S., Holger S., David I.S., Torsten U., Martino B. Structure and functionally in flavivirus NS-proteins: Perspectives for drug design. Antiviral Research, 2010; 87(1): 125-148.

10. Pierson T.C., Diamond M.S. Degrees of maturity: the complex structure and biology of flavivirus. Current Opinion in Virology, 2012; 2(2): 168-175. https://doi.org/10.1016/j.coviro.2012.02.011.

11. Lin H., Tao L., Tie S., Lifeng L., Jianpeng X., Jinyan L., Jianfeng H., Haojie Z., Wenbiao H., Aiping D., Zhiqiang P., Wenjun M., Yonghui Z. Community involvement in dengue outbreak control: An Integrated Rigorous Intervention Strategy. PLOS Neglected Tropical Diseases. 2016; 10(8): 1-10. https://doi.org/10.1371/journal.pntd.0004919.

12. Rigau-Perez J.G. Severe dengue: the need for new case definitions. Lancet, 2006; 6(1):297-302. https://doi.org/10.1016/S1473-3099(06)70465-0.

13. Van Dam A.R., Walton W.E. The effect of predatory fish exudates on the ovipositiona; behavior of three mosquito species: Culex quinquefasciatus, Aedes aegypti and Culex tarsalis. Medical and Veterinary Entomology, 2008; 22(1): 399-404. https://doi.org/10.1111/j.1365-2915.2008.00764.x.

14. Cameron P.S., Jeremy J.F., Nguyen V., Bridget
W. Dengue. The New England Journal of Medicine, 2012; 366(1): 1423-1432. https://doi.org/10.1056/NEJMra1110265.

15. Bijaya M., Ashok S., Saurabh P. Clinicolaboratory profile of expanded dengue syndrome - Our experience in a teaching hospital. Journal of Family Medicine and Primary Care, 2019; 8(3): 1022-1027. https://doi.org/10.4103/jfmpc.jfmpc_12_19.

16. Cardoso C.W., Igor A.D.P., Mariana K., Morenos R., Monaise M.O.S., Gubio S.C., Silvia I.S., Uriel K., Mitermayer G.R., Guilherme S.R. Outbreak of exanthematous illness associated with Zika, Chikungunya and Dengue viruses, Salvador, Brazil. Emerging Infectious Disease, 2015; 21(1): 2274-2276. https://doi.org/10.3201/eid2112.151167.

17. Blacksell S.D., Mammen M.P., Thongpaseuth S. Evaluation of the Panbio dengue virus nonstructural 1 antigen detection and immunoglobulin $\mathrm{M}$ antibody enzyme-linked immunosorbent assays for the diagnosis of acute dengue infections in Laos. Diagnostic Microbiology and Infectious Disease, 2007. https://doi.org/10.1016/j.diagmicrobio.2007.07.011.

18. Vaddadi S., Vaddadi R. Dengue fever: A review article. Journal of Evolution of Medical and Dental Sciences, 2015; 29(1): 5049-5058.

19. Chien L.J., Liao T.L., Shu P.Y. Development of real-time reverse transcriptase PCR assays to detect and serotype dengue viruses. Journal of Clinical Microbiology, 2006; 44(1): 1295-1297. https://doi.org/10.1128/JCM.44.4.1295-1304.2006.

20. Moi M.L., Takasaki T., Saijo M., Kurane I. Dengue virus infection - enhancing activity of undiluted sera obtained from patients with secondary dengue virus infection. Transactions of the Royal Society of Tropical Medicine and Hygiene, 2013; 107(1): 51-58. https://doi.org/10.1093/trstmh/trs007.

21. Srikiatkhachorn A., Krautrachue A., Ratnaprakarn W. Natural history of plasma leakage in dengue hemorrhagic fever; a serial ultrasonographic study. Pediatric Infectious Disease Journal, 2007; 26(1): 283-287. https://doi.org/10.1097/01.inf.0000258612.26743.10.

22. Anum J., Fatima N., Momna M., Faqeeha J., Qurban A., Shahbaz A., Muhammad F., Idrees A. Dengue Fever: Causes, Prevention and Recent Advances. Journal of Mosquito Research, 2016; 6(29): 1-17.

23. Singh R.K., Kuldeep D., Karthik K., Tiwari R., Khandia R., Ashok M., Hafiz M.N.I., Yashpal S.M., Ruben B.M. Advances in Diagnosis, Surveillance, and Monitoring of Zika Virus: An Update. Frontiers in Microbiology, 2018; 8:2677-2700. https://doi.org/10.3389/fmicb.2017.02677.

24. Mario A.R., Annabel F.V.H., Filiberto R.V. Biological control of dengue vectors. Integrated Pest Management and Pest Control - Current and Future Tactics, 2012; 1(1): 241-270.

25. Muhammad S. Reducing dengue fever through biological control of disease carrier Aedes Mosquitoes (Diptera: Culicidae). International Journal of Preventive Medicine Research, 2015; 1(3): 161-166.

26. McMeniman C.J., Lane R.V., Cass B.N., Fong A.W., Sidhu M., Wang Y.F., O'Neill S.L. Stable introduction of a life-shortening Wolbachia infection into the mosquito 
Aedes aegypti. Science, 2009; 323(1): 141-144. https://doi.org/10.1126/science.1165326.

27. Lalithambika B., Vani C. Pseudomonas aeruginosa KUN2, extracellular toxins - A potential source for the control of dengue vector. Journal of Vector Borne Disease, 2016; 53(1):105-111.

28. Rothan H.A., Zulqarnain M., Ammar Y.A., Tan E.C., Rahman N.A., Yusof R. Screening of antiviral activities in medicinal plants extracts against dengue virus using dengue NS2B-NS3 protease assay. Trop. Biomed., 2014; 31(2): 286-96.

29. Huang N., Hung W., Tsai W., Lai F., Lin Y., Huang M., Chen J., Lin W., Weng J., Chang T. Ficus septica plant extracts for treating Dengue virus in vitro. Peer J., 2017; 1-12. https://doi.org/10.7717/peerj.3448.

30. Perera S.D., Jayawardena U.A., Jayasinghe C.D. Potential Use of Euphorbia hirta for Dengue: A Systematic Review of Scientific Evidence. Journal of Tropical Medicine, 2018; 1-7. https://doi.org/10.1155/2018/2048530.

31. Ahmad N., Fazal H., Ayaz M., Abbasi B.H., Mohammad I., Fazal L. Dengue fever treatment with Carica papaya leaves extracts. Asian Pacific Journal of Tropical Biomedicine, 2011; 1(4): 330-3. https://doi.org/10.1016/S2221-1691(11)60055-5.

32. Wahab N.Z.A., Ibrahim N., Kamarudin M.K.A., Lananan F., Juahir H., Ghazali A., Ireana A.F. Cytotoxicity and Antiviral Activity of Annona Muricata Aqueous Leaves Extract Against Dengue Virus Type 2. Journal of Fundamental and Applied Sciences, 2018; 10(1S): 580-589.

33. Ichsyani M., Ridhanya A., Risanti M., Desti H., Ceria R., Putri D.H., Sudiro T.M., Dewi B.E. Antiviral effects of Curcuma longa $\mathrm{L}$. against dengue virus in vitro and in vivo. Earth and Environmental Science, 2017; 101. https://doi.org/10.1088/1755-1315/101/1/012005.

34. Agarwal M.J., Chanda S., Rao M.E., Ganju L. Effect of Hippophae Rhamnoides Leaf Extract against Dengue Virus Infection in U937 Cells. Virol-mycol., 2016; 5: 157. https://doi.org/10.4172/2161-0517.1000157.

35. Oliveira A.F., Teixeira R.R., Oliveira A.S., Souza A.P., Silva M.L., Paula S.O. Potential Antivirals: Natural Products Targeting Replication Enzymes of Dengue and Chikungunya Viruses. Molecules, 2017; 22(3): 505. https://doi.org/10.3390/molecules22030505.

36. Singh P.K., Rawat P. Evolving herbal formulations in management of dengue fever. Journal of Ayurveda and Integrative Medicine, 2017; 8(3): 207-210. https://doi.org/10.1016/j.jaim.2017.06.005.

37. Bilal H., Akram W., Hassan S.A., Din S. Citrus Seed Oils Efficacy against Larvae of Aedes aegypti. Journal of
Arthropod-borne Diseases, 2017; 11(3): 427-432.

38. Klawikkan N., Nukoolkarn V., Jirakanjanakit N., Yoksan S., Wiwat C., Thirapanmethee K. Effect of Thai Medicinal Plant Extracts against Dengue Virus in vitro. Journal of Pharmaceutical Science, 2011; 38 (1-2): 1318.

39. Seng C.M., Setha T., Nealon J., Socheat D., Chantha N., Nathan M.B. Community-based use of the larvivorous fish Poecilia reticulata to control the dengue vector Aedes aegypti in domestic water storage containers in rural Cambodia. Journal of Vector Ecology, 2008; 33(1): 139-144. https://doi. org/10.3376/1081-1710(2008)33[139:CUOTLF]2.0. $\mathrm{CO} ; 2$.

40. Chansang U., Zahiri N.S., Bansiddhi J., Boonruad T., Thongsrirak P., Mingmuang J., Benjapong N., Mulla M.S. Mosquito larvicidal activity of aqueous extracts of long pepper (Piper retrofractum Vahl) from Thailand. J. Vector Ecol., 2005; 30(2): 195-200.

41. Asad S., Hussain M., Hugo L., Osei-Amo S., Zhang G., Watterson D., Asgari S. Suppression of the pelo protein by Wolbachia and its effect on dengue virus in Aedes aegypti. PLoS Negl Trop Dis., 2018; 12(4). https://doi.org/10.1371/journal.pntd.0006405.

42. Campos Jתnior E.Od., Silva C.F., Silva C.Rd., Pereira B.B., Caixeta E.S., Paula M.B.Cd., Silva J.Jd., Reis A.Ad., Cunha F., Souza A.Ad. Validation of the Species Xiphophorus Maculatus For Biological Control Of Aedes Aegypty By Comparing Its Larvae-Eating Potential With Poecilia Reticulate. Biological Control. 2017. https://doi.org/10.1016/j.biocontrol.2017.08.021.

43. Hidari K.I., Takahashi N., Arihara M., Nagaoka M., Morita K., Suzuki T. Structure and anti-dengue virus activity of sulfated polysaccharide from a marine alga. Biochem Biophys Res. Commun., 2008; 376(1): 91-5. https://doi.org/10.1016/j.bbrc.2008.08.100.

44. Lokesh R., Barnabas E.L., Madhuri P., Saurav K., Sundar K. Larvicidal Activity of Trigonella foenum and Nerium oleander Leaves Against Mosquito Larvae Found in Vellore City, India. Current Research Journal of Biological Sciences, 2010; 2(3): 154-160.

45. Parida M.M., Upadhyay C., Pandya G., Jana A.M. Inhibitory potential of neem (Azadirachta indica Juss) leaves on Dengue virus type-2 replication. J. Ethnopharmacol., 2002; 79: 273-278. https://doi.org/10.1016/S0378-8741(01)00395-6.

46. Deep P., Srivastava V., Verma S. Current Perspectives of Medicinal Plants Having Anti Dengue Potential. Int. J. Pharm. Sci. Rev. Res., 2018; 49(2): 91-96. 